\title{
Age structure, carbonate production and shell loss rate in an Early Miocene reef of the giant oyster Crassostrea gryphoides
}

\author{
Mathias Harzhauser ${ }^{1}$, Ana Djuricic ${ }^{2}$, Oleg Mandic ${ }^{1}$, Thomas A. Neubauer ${ }^{1}$, Martin Zuschin ${ }^{3}$, and Norbert Pfeifer ${ }^{2}$ \\ ${ }^{1}$ Natural History Museum Vienna, Geological-Paleontological Department, Vienna, Austria \\ ${ }^{2}$ TU Wien, Department of Geodesy and Geoinformation, Vienna, Austria \\ ${ }^{3}$ University of Vienna, Department of Paleontology, Vienna, Austria
}

Correspondence to: Mathias Harzhauser (mathias.harzhauser@nhm-wien.ac.at)

Received: 22 July 2015 - Published in Biogeosciences Discuss.: 28 September 2015

Revised: 15 February 2016 - Accepted: 16 February 2016 - Published: 29 February 2016

\begin{abstract}
We present the first analysis of population structure and cohort distribution in a fossil oyster shell bed based on 1121 shells of the giant oyster Crassostrea gryphoides (von Schlotheim, 1813). Data derive from terrestrial laser scanning of a Lower Miocene shell bed covering $459 \mathrm{~m}^{2}$. Within two transects, individual shells were manually outlined on a digital surface model and cross-checked based on high-resolution orthophotos, resulting in accurate information on center line length and area of exposed shell surface. A growth model was calculated, revealing this species as the fastest growing and largest Crassostrea known so far. Non-normal distribution of size, area and age data hints at the presence of at least four distinct recruitment cohorts. The rapid decline of frequency amplitudes with age is interpreted to be a function of mortality and shell loss. The calculated shell half-lives range around a few years, indicating that oyster reefs were geologically short-lived structures, which could have been fully degraded on a decadal scale.

Crassostrea gryphoides reefs were widespread and common along the Miocene circum-Tethyan coasts. Given its enormous growth performance of $\sim 150 \mathrm{~g}$ carbonate per year this species has been an important carbonate producer in estuarine settings. Yet, the rapid shell loss impeded the formation of stable structures comparable to coral reefs.
\end{abstract}

\section{Introduction}

The genus Crassostrea Sacco (1897) comprises numerous commercially exploited species. The modes of growth and population structures of extant Crassostrea species are of paramount importance for oyster fishery (FAO, 2015). Consequently, a wealth of data exists on the ontogeny, biology and ecological requirements. These data, in turn are a valuable base for the interpretation of the autecology of fossil congeners. Extant Crassostrea are sessile bivalves adapted to estuarine and intertidal environments where they have to cope with high environmental stress. Whilst physicochemical stress is managed by genetic response (Zhang et al., 2012), the formation of thick shells is a strategy against predation (Lombardi et al., 2013; Robinson et al., 2014). The largest and fastest growing Crassostrea species flourished during the Miocene and Early Pliocene and became replaced by comparatively smaller and thinner species thereafter (Kirby and Jackson, 2004). Among these, Crassostrea gryphoides (von Schlotheim, 1813) is the largest, attaining shell lengths of up to $80 \mathrm{~cm}$ and individual ages of more than 40 years (Harzhauser et al., 2010). The Pleistocene-Holocene extirpation of large and thick-shelled Crassostrea species was explained by a shift from shallow-marine towards estuarineintertidal habitats to escape from predation (Kirby, 2000, 2001). At least for $C$. gryphoides this model does not fit because the oyster lived as secondary soft-bottom dweller in the intertidal zone of estuaries along the circum-Tethyan coasts (Laurain, 1980; Schultz, 2001; Mandic et al., 2004). This species evolved during the Late Oligocene in the European Paratethys Sea and became ubiquitous in the Paratethys Sea, the proto-Mediterranean Sea and the eastern Atlantic throughout the Early to Late Miocene. It might even have entered the Indian Ocean during the Miocene (Newton and Smith, 1912) and reached the North Sea during the Middle Miocene (Schultz, 2001). Pliocene records from the eastern 
Atlantic and North Africa, however, may need verification (see Schultz, 2001 for a detailed list of occurrences). This species became extinct around the Miocene/Pliocene boundary or with the onset of the Pliocene cooling $3 \mathrm{Ma}$ ago at the latest.

Studies on growth in fossil Crassostrea species (and other oysters) and the resulting carbonate production were published by Chinzei (1982, 1986, 1995), Chinzei and Seilacher (1993), Kirby (2001) and Kirby and Jackson (2004). These studies are based on collection material comparing species and specimens from different stratigraphic horizons. No study, however, tried to capture the size and age structures of a fossil Crassostrea reef, presumably representing a real population of coeval specimens. The lack of such studies is clearly linked to the fact that fossil shell beds usually represent time-averaged assemblages (Kidwell, 1986, 1991), which only vaguely reflect original community structures. Although some in situ preserved fossil Crassostrea reefs are known (e.g., Hoşgör, 2008; Ragaini and Di Celma, 2009; Chinzei, 2013) no population data exist, which would allow a comparison with modern oyster reefs. Herein, we analyze an Early Miocene Crassostrea shell bed covering an area of $459 \mathrm{~m}^{2}$, which is permanently exposed at a geopark in Austria. The shells are concentrated in a sheetlike, ca. $20 \mathrm{~cm}$ thickness layer, which was formed by a major storm or tsunami, amalgamating a single oyster reef in an event bed (Fig. 1a-c). Although the hydrodynamic process will have biased the original structure to some degree, our data suggest that no out-of-habitat transport occurred and the shell bed still reflects the original composition and thus the population structure of an oyster reef from the onset of the Miocene Climatic Optimum (Zachos et al., 2008; Goldner et al., 2014).

Crassostrea reefs flourished during the Miocene within the tropical reef belt (Mandic et al., 2004) but were also successful in more northern latitudes (Wiedl et al., 2013; Harzhauser et al., 2010). Therefore, the main purpose of this paper is to quantify the growth performance of the Miocene giant oyster and to reveal its significance as part of the Miocene "carbonate factory". Moreover, we test whether size-frequency data deduced from fossil oyster shells allow a comparison with community structures of extant Crassostrea reefs.

\section{A taxonomic note}

Although the type of Crassostrea gryphoides (von Schlotheim, 1813) was described from the mid-Miocene of Romania, the name is also used in biological literature for an extant backwater species from India and Pakistan (Newton and Smith, 1912; Chatterji et al., 1985; Nagi et al., 2011; Afsar et al., 2014; Trivedi et al., 2015). The taxonomic status of the extant species is unclear; based on molecular data, Reece et al. (2008) considered C. "gryphoides" to be closely related with $C$. belcheri (Sowerby, 1871), whilst molecular data of Trivedi et al. (2015) suggest a close rela-

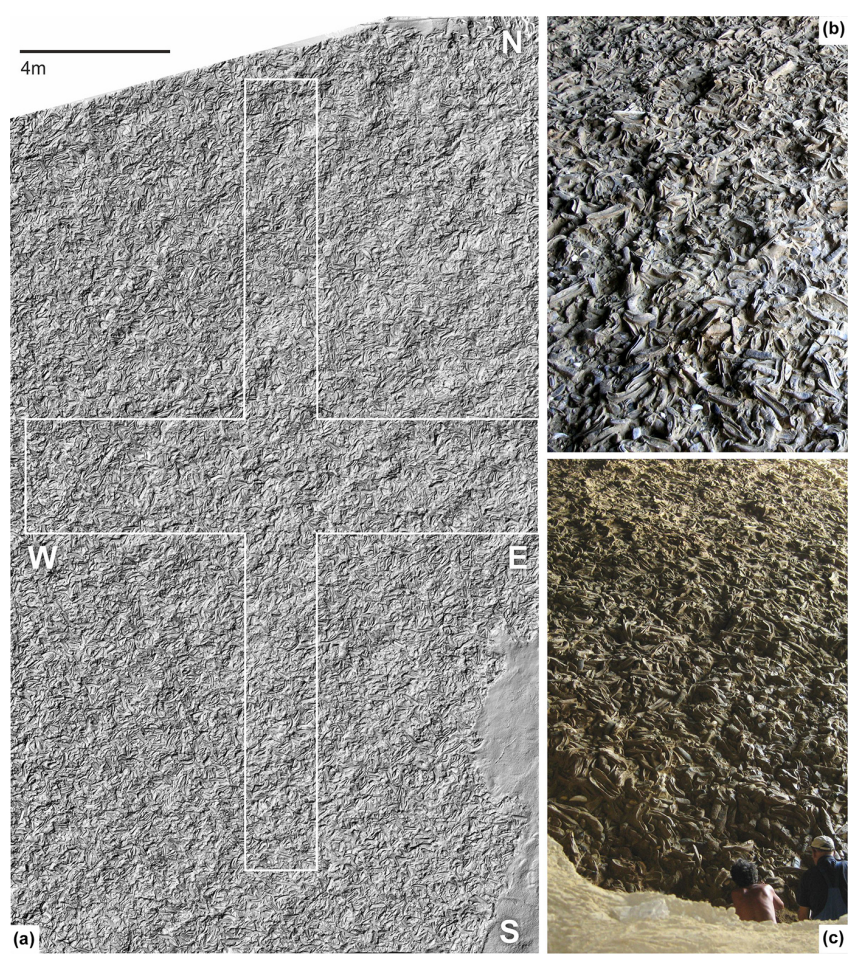

Figure 1. Part of the digital surface model of the shell bed; the white cross indicates the area, within which all objects were digitally outlined and evaluated. It contains 1121 complete shells of C. gryphoides and 7047 fragments of that species (a). Outcrop pictures of the shell bed illustrating the density and extent of the shell bed (b-c), (b) width ca. $2 \mathrm{~m}$; (c) see workers as scale.

tion with C. cuttackensis (Newton and Smith, 1912), which was originally described as subspecies of $C$. gryphoides. Whatever the taxonomic and systematic status of the recent species may be, it is most probably not conspecific with the European fossil species. It differs in its more regular and elongate-ovoid outline (Durve and Bal, 1960), in the short and bean-shaped adductor muscle scar (Durve, 1974; Siddiqui and Ahmed, 2002) and in it being more inequivalved. Overall, the recent species is clearly smaller with the largest specimen documented so far attaining $508 \mathrm{~mm}$ in length (Mahar and Awan, 2012) but usually ranging around 50-120 mm (Chatterji et al., 1985; Nagi et al., 2011).

Nevertheless, the Miocene species is closely related to the extant Asian-Pacific Crassostreinae species, which show a large genetic difference from Atlantic species (Littlewood, 1994; Ó Foighil et al. 1995; Wang et al., 2004; Ren et al., 2010; Salvi et al., 2014). The Asian-Pacific group (e.g., $C$. gigas, C. plicatula, C. ariakensis) and Atlantic group (e.g., C. virginica, C. rhizophorae, C. gasar) differ considerably in mitochondrial genes, nuclear genome and chromosome structures (Wang et al., 2004; Ren et al., 2010; Salvi et al., 2014). The divergence between both groups seems to have happened already in Cretaceous times and the diversification of the Asian-Pacific group started during the Eocene (Ren et 
al., 2014). Based on this genetic evidence and biogeographic separation, Salvi et al. (2014) introduced the genus Magallana Salvi et al. (2014) for the Asian-Pacific species group with Ostrea gigas Thunberg (1793) as type species. Salvi et al. (2014), however, did not provide a formal "description or definition that states in words characters that are purported to differentiate the taxon" (ICNZ Art. 13.1.1). The authors only refer to a description of the type species. Therefore, Magallana is formally unavailable (see also Marshall, 2015) and we use Crassostrea in its traditional sense.

\section{Geological setting and paleoenvironment}

The investigated oyster shell bed was excavated at Stetten in Lower Austria $\left(48^{\circ} 22^{\prime} 03.33 \mathrm{~N}, 16^{\circ} 21^{\prime} 33.22 \mathrm{E}\right)$. It is part of the about $600 \mathrm{~m}$ thick lower Miocene (upper Burdigalian $=$ Karpatian regional stage) siliciclastic succession of the Korneuburg Basin, which is a $20 \mathrm{~km}$ long and $7 \mathrm{~km}$ wide halfgraben within the Alpine-Carpathian thrust-belt (Fig. 2) (Wessely, 1998). The basin fill is dominated by an alternation of shoreface and tidal flat deposits, which were formed in an embayment of the Paratethys Sea (Zuschin et al., 2014). More than 650 species-level taxa have been described from the area (Sovis and Schmid, 1998, 2002) and the paleoenvironments are well understood (Harzhauser et al., 2002; Zuschin et al., 2014). The oyster reef flourished in an estuary fringed by salt marshes, Taxodiaceae swamps and scattered Avicennia mangroves (Harzhauser et al., 2002; Kern et al., 2010). The pollen record of the Stetten section documents a warm subtropical climate with marked seasonality (Kern et al., 2010). A warm and wet summer season with ca. $204-236 \mathrm{~mm}$ precipitation during the wettest month was alternating with a rather dry winter season with precipitation of ca. 9-24 mm during the driest month. The mean annual temperature ranged between 15.7 and $20.8^{\circ} \mathrm{C}$, with about 9.6-13. ${ }^{\circ} \mathrm{C}$ during the cold season and $24.7-27.9^{\circ} \mathrm{C}$ during the warmest month. These data suggest similarities with the modern "Cwa" climate of Köppen (1936). Today this climate covers parts of northern India extending into southeastern Asia (southern Nepal, Myanmar, northern Thailand) to East China and in central/south Africa (eastern Angola, Zambia, northern Zimbabwe, northern Mozambique) (Peel et al., 2007; Kern et al., 2010). The distinct seasonality was also revealed in sclerochronologic analysis of one of the Crassostrea shells collected from the shell bed (Harzhauser et al., 2010). This shell exhibits a regular annual rhythm of at least 11 seasons with a temperature range of $9.8^{\circ} \mathrm{C}$. Thus, the paleoclimatic and paleoenvironmental frame of the $C$. gryphoides shell bed is comparable to the settings of modern Crassostrea reefs in the subtropical parts of the Asian Pacific.

The fossil shell bed was excavated in a 3-month campaign by the Natural History Museum Vienna in 2008. The oyster bed was covered by up to $10 \mathrm{~m}$ of silty sand and clay, which

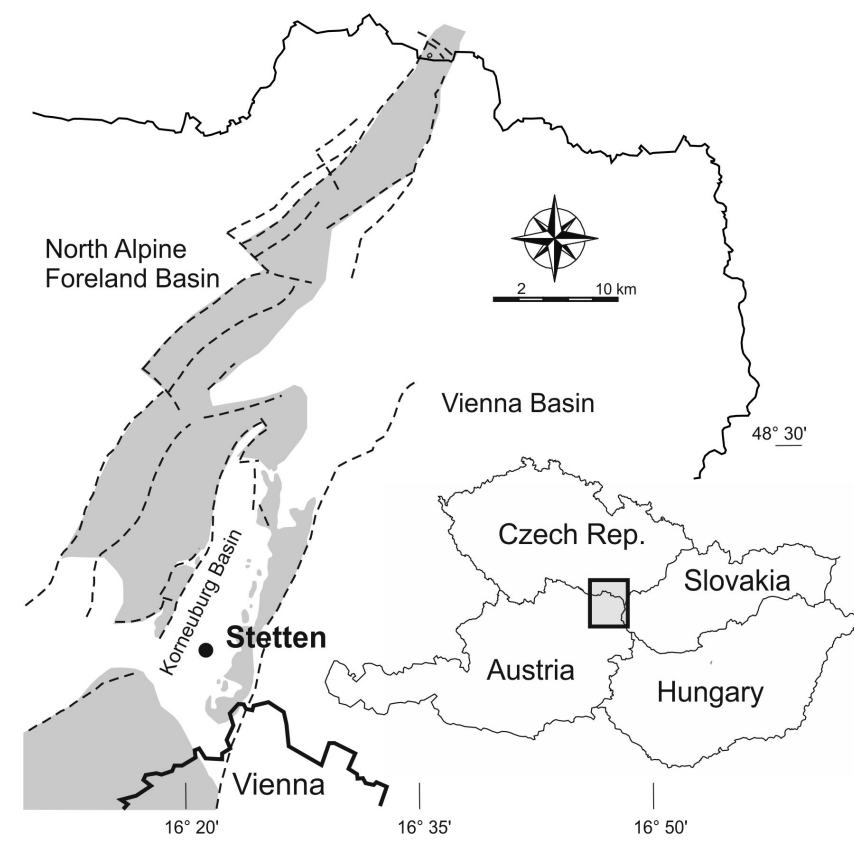

Figure 2. Geographic position of the Stetten site within the Korneuburg Basin north of Vienna in Austria; shaded areas represent pre-Miocene basement; dashed lines are major faults (modified from Dellmour and Harzhauser, 2012).

was successively removed. Due to the largely unconsolidated state of the surrounding silty sand, the excavation of the shell bed could be done manually with steel gravers and brushes; no water or any chemicals were added and all shells and fragments remained in their original position. The oyster shells themselves are well preserved and robust. Therefore, no artificial fragmentation occurred during the excavation.

Originally, the shell bed was nearly flat at the time of deposition but has now an undulate surface due to postsedimentary tectonic activity. This tectonic phase occurred during the Middle Miocene at least 1-2 million years after deposition and caused a tilting of the units of ca. $25^{\circ}$ in the western direction. During that tilting, a NW-SE trending fault system developed that caused the current relief. Locally, the displacement by the faults is in the range of a few centimeters.

Harzhauser et al. (2015) describe the complex taphonomy of the shell bed, which was formed by a tsunami or an exceptional storm and represents an event deposit sensu Einsele et al. (1991) and Kidwell (1991). As discussed by Harzhauser et al. (2015), the assemblage is not monospecific but contains about 46 molluscan species of which Crassostrea gryphoides predominates in individual numbers $(79.4 \%)$. The species, such as the potamidid gastropod Ptychopotamides papaveraceus and the venerid bivalve Venerupis basteroti, lived partly within the oyster reef or were admixed from adjacent mudflats and shallow sublittoral habitats. As shown by Harzhauser et al. (2015), the fossil bed is parautochthonous. Although the oyster shell bed is clearly not in situ but re- 

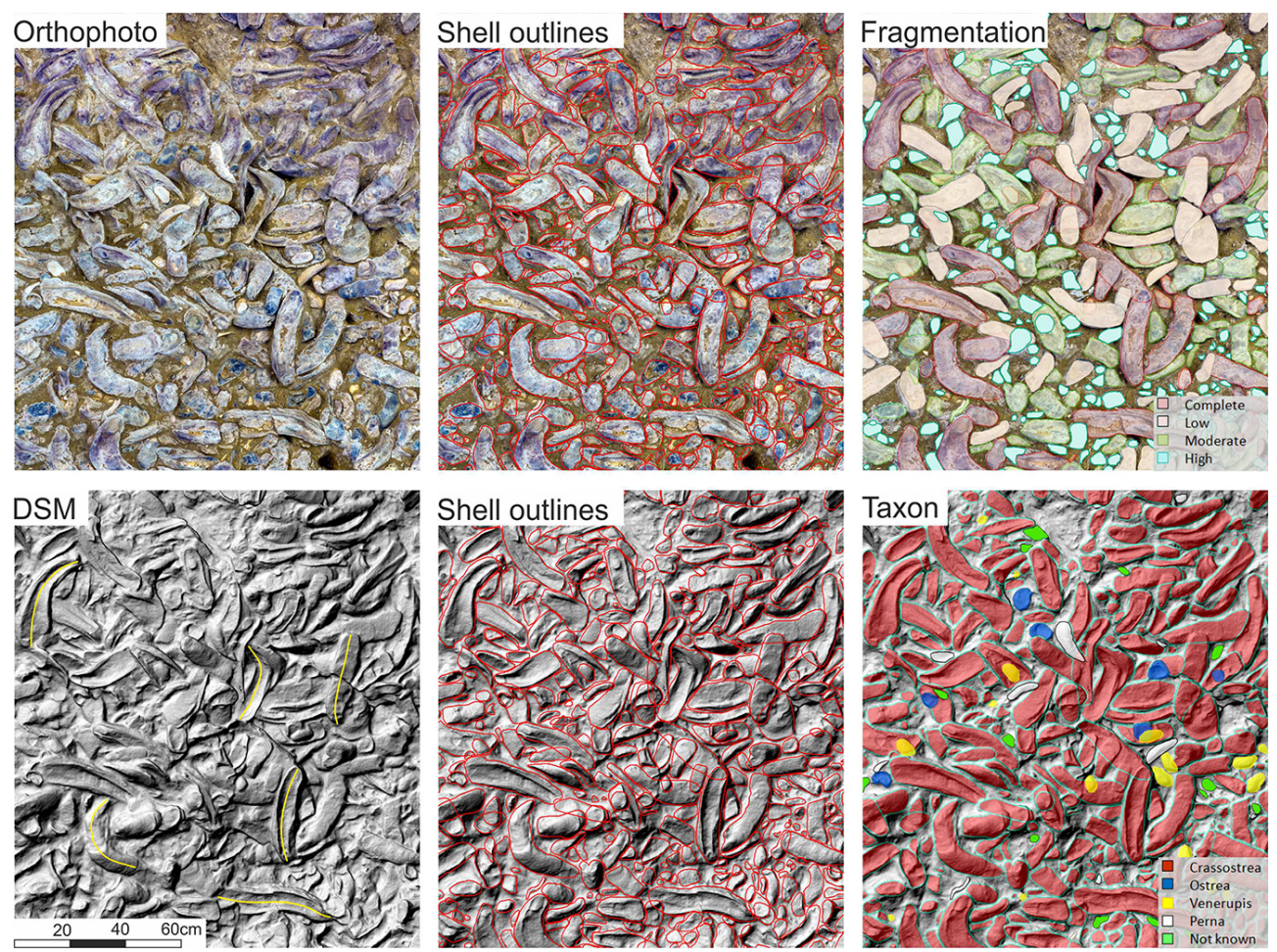

Figure 3. Examples of the data acquisition: orthophoto and digital surface model (DSM) are used to define shell outlines manually. Together with various attributes, such as degree of fragmentation and taxon ID, these data are georeferenced in an ArcGIS database. Yellow lines in the DSM are examples of center lines.

worked, the original community structure still seems to be reflected, which is the basic working hypothesis of this paper. Lack of sorting is indicated by the accumulation of very small and very large shells. Similarly, the equal contribution by left and right valves points to the preservation of the primary composition and contradicts the hypothesis of hydrodynamic sorting and selective transport. Despite the bias of post-event processes, when the exhumed shells were exposed for a few years on the seafloor, the rapid subsequent burial preserved most of the original distribution patterns.

\section{Materials and methods}

\subsection{Data acquisition by terrestrial laser scanning and orthophotos}

Terrestrial laser scanning has triggered a revolution in topographic terrain capturing, especially in the generation of digital terrain models. Methods for generating such models from laser scanning data are discussed by Kraus and Pfeifer (2001) and references therein. Terrestrial laser scanning was applied to document the site as georeferenced 3-D point cloud (Otepka et al., 2013). A Faro Focus Laser scanner with a nominal point measurement accuracy of $1 \mathrm{~mm}(\mathrm{SD})$ in each coordinate and a sampling distance of approximately $1 \mathrm{~mm}$ was used. The individual point clouds of each scan were transformed first into one common coordinate system and then georeferenced by control points to Universal Transverse Mercator (UTM) coordinates (resolution below $2 \mathrm{~mm}$ ). A robust filter (pre-processing) was applied to reduce measurement noise while preserving surface structures like sharp edges (Nothegger and Dorninger, 2009). The surface triangulation is based on the Poisson surface reconstruction method (Kazhdan et al., 2006). The points of this triangulation are used for interpolating a regular grid of heights above the plane of the shell bed using the scientific software OPALS (Pfeifer et al., 2014). In addition, a Canon 60D with a Canon EF $20 \mathrm{~mm}$ f2.8 was used to capture more than 300 photos from a moving platform. The camera was placed approximately orthogonal to the fossil bed. From the photos with a nominal ground resolution of approximately $0.6 \mathrm{~mm}$ per pixel an orthophoto mosaic was generated with a resolution of $0.5 \mathrm{~mm}$ per pixel. To detect patterns in the distribution and composition of shells two transects (N-S, W-E) were defined, each represented by $42 \mathrm{~m}^{2}$ with a central overlap (Fig. 1). All objects within this area were manually outlined on the digital surface model and cross-checked based on the high-resolution orthophotos (Fig. 3).

Manual outlines are vector data sets in the form of manually digitized polygons representing the boundaries of the identified specimens. They are created as thematic layer in an ArcGIS environment. The polygon is defined by features 

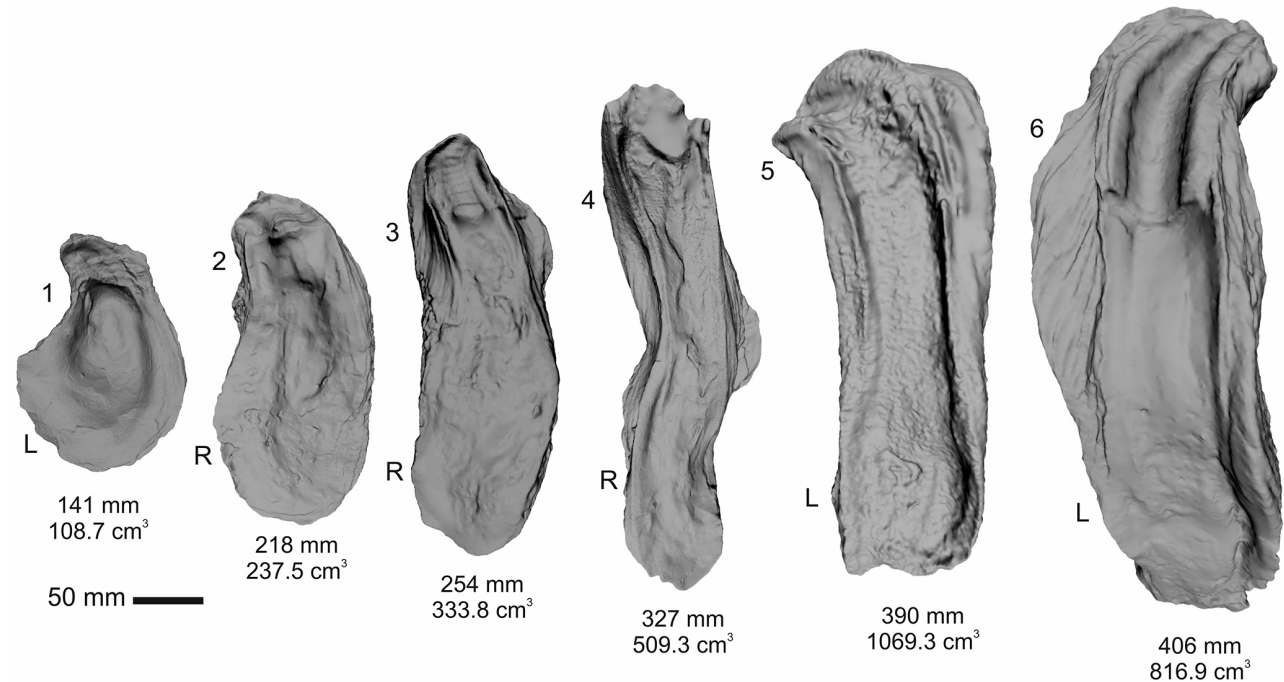

Figure 4. Models of six shells based on high-resolution laser scanning data of shells from the collections of the Natural History Museum. These specimens document the broad range of morphologies and were used for volume calculations; $\mathrm{L}=$ left shell, $\mathrm{R}=$ right shell.

such as points (i.e., vertices connected with lines). Each polygon is a 2-D visual representation of the manually digitized specimen from the adequate orthophoto and its corresponding digital surface model. Further, manually digitized data are organized into a table. This tabular structure has its elements, i.e., numerical and descriptive attributes. For instance, numerical attributes are ID, length, orientation, etc. Descriptive attributes are taxon, side (left, right, unknown), state of preservation (complete, low, moderate, high fragmented), etc.

The outline data are composed of about 1000 virtual points (nodes) on average per object and are also stored in the georeferenced ArcGIS database. These allow an automatic calculation of the surface area of each object by using the $\mathrm{Cal}$ culate Geometry tool.

In total, 10284 objects were defined. Of these, 8168 objects were identified as Crassostrea gryphoides of which 1121 are complete shells (see supplementary table); $86 \%$ of the specimens display various degrees of fragmentation and are excluded from the size-frequency analysis. Four categories of fragmentation were used: complete shells are fully preserved or display only minor damage, which might have occurred already during the life of the animal $(n=$ 1121). The category "low fragmentation" comprises shells in which not more than $1 / 2$ of the assumed length is missing $(n=951)$. Moderate fragmentation is defined by representing at least $1 / 2$ of the original shell lengths $(n=1638)$. The category "high fragmentation" comprises 4458 specimens of strongly damaged shells representing less than $1 / 4$ of the complete shell. Note that the attribute fragmentation does not contain any information on abrasion. The fragments usually show sharp fractures, and therefore the main cause for fragmentation seems to be predatory and hydrodynamic breakage. The ratio between left and right valves is balanced (0.98). The distribution of the shells is not uniform, occasionally featuring areas of higher shell densities, which seem to reflect former colony-like concentrations.

\subsection{Shell length and area}

Crassostrea gryphoides shows a very broad range of morphologies, ranging from elongate shells to strongly curved and sigmoidal shapes (Fig. 4). Therefore, measuring shell length as a straight line, as done in other extant and fossil Crassostrea species, is inadequate. To overcome this problem, we evaluated shell length based on the 2-D center line. Center line length is the term used in photogrammetry and aims for capturing the real shell length as far as possible. Here it is an imaginary curved line spanning the maximum length of the shell. The advantage of this method is that the center line will approximate the "real" lengths of the curved and irregularly shaped shells much better than any manual attempt in the field.

For the automatic determination of the center line we used the shell margins, which comprise about 1000 points on average. For easier calculation the outline point number was reduced to 100 and then filtered to points with close to even spacing. In the next step, a Delaunay triangulation was calculated between the filtered outline points (Delaunay, 1934), constrained by the edges between the outline points. To find the center line for each oyster outline, the Voronoi diagram was formed (Voronoi, 1908) from the triangulation. The edges between neighboring Voronoi vertices within the boundary are the medial axis transform (MAT) for the oyster outline (Aichholzer et al., 1996). The longest 2-D path in this tree was found using Dijkstra's algorithm between MAT end points (Kirk, 2015). 


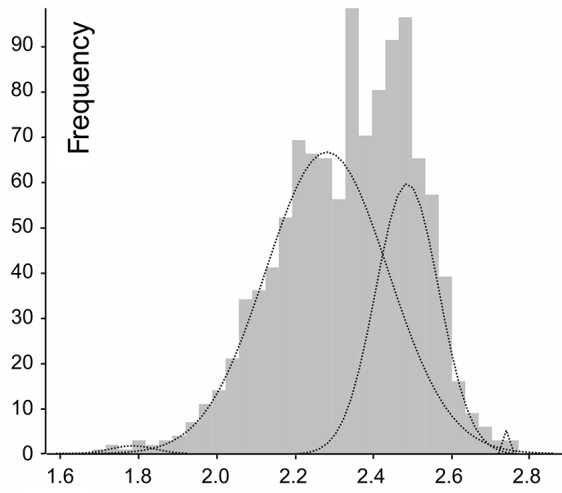

(a)

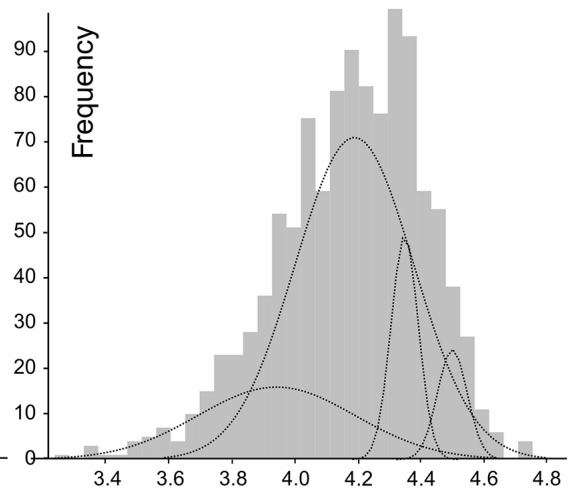

(b)

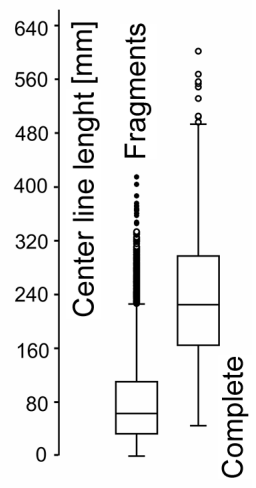

(c)

Figure 5. Size-frequency diagrams for center line length and area data (log transformed) with cohorts (dashed lines) as detected by mixture analysis $(\mathbf{a}, \mathbf{b})$. Box-plot illustrating the strongly right-skewed distribution for fragments $(n=7047)$ and a clear separation from the size distribution pattern of complete shells $(n=1121)(\mathbf{c})$.

The center line lengths of 1121 complete Crassostrea shells, rounded to the nearest $\mathrm{mm}$, range from 48 to $602 \mathrm{~mm}$ with a mean of $237 \mathrm{~mm}(\sigma=89 \mathrm{~mm})$ (Fig. 5a). The data distribution displays a positive skewness of 0.52 and the Shapiro-Wilk test excludes normal distribution for raw data and $\log 10$-transformed measurements. Area data range from 1708 to $56755 \mathrm{~mm}^{2}$ with a mean of $16983 \mathrm{~mm}^{2}$ $\left(\sigma=8414 \mathrm{~mm}^{2}\right)$ (Fig. $5 b$ ). These data show also a positive skewness $(0.83)$ and normal distribution is rejected by the Shapiro-Wilk test.

Based on the manual outlines, the exposed shell area can be deduced directly. Area data are slightly underestimated because shells are not always exposed parallel to the bedding plane but may be somewhat oblique. Despite the fact that area data are somewhat biased by oblique shells, the correlation between center line lengths and areas is highly significant (raw data: $r=0.92, p<0.001$; $\log 10$-transformed: $r=0.93, p<0.001$ ) (Fig. 6).

\subsection{Length-frequency data}

Non-normal distribution of length-frequencies is a common pattern in extant Crassostrea reefs (e.g., Coakley, 2004; Baqueiro Cárdenas and Aldana Aranda, 2007; Harding et al., 2008; Nurul Amin et al., 2008; Ross and Luckenbach, 2009; Goslier et al., 2014). It results from seasonal and/or annual recruitment with distinct cohorts (sensu Powell et al., 2006, 2015; Southworth et al., 2010). For instance, the (sub)tropical C. madrasensis and C. rhizophorae display a distinct annual recruitment peak (Nurul Amin et al., 2008; Mancera and Mendo, 1996). In multiannual communities this results in a right-skewed distribution due to the loss of old specimens by natural mortality and shell loss. For extant Crassostrea reefs, the analysis of the cohorts is routinely performed using Bhattacharya's model or the EM-Algorithm of Dempster et al. (1977), which tries to detect normal dis-

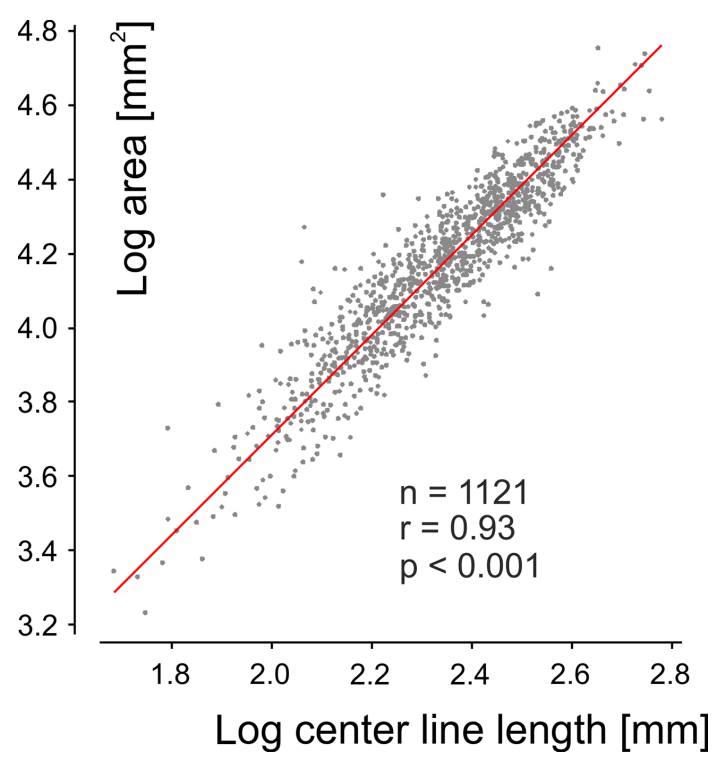

Figure 6. Regression analysis revealing a significant correlation between length and area of complete shells.

tributions within the length-frequency data. Consequently, in order to test for cohort mixing, lengths of $C$. gryphoides were subjected to mixture analysis, a maximum-likelihood method for estimating the parameters of two or more univariate normal distributions, based on a pooled univariate sample (Hammer, 2015). Statistical analyses were performed in PAST versions $2.17 \mathrm{c}$ and 3.06 (Hammer et al., 2001). Akaike's information criterion (AIC) was used to test the goodness of fit of the maximum likelihood estimates to the length-frequency data.

In $\log 10$-transformed length frequency diagrams, the maximum likelihood based analysis reveals lowest AIC values for four or five cohorts. Similarly, log-transformed area data 
have lowest AIC values if four or five cohorts are detected. The assumption of more groups does not lower the AIC, or the computed cohorts comprise unrealistic narrow cohort ranges, which are nested within larger ones.

\subsection{Growth model}

Kirby et al. (1998), Kirby (2000, 2001) and Kirby and Jackson (2004) used ligamental increments of fossil and recent Crassostrea species to estimate individual life spans, assuming that increments are formed annually. The ligamental area of these Crassostrea species is typically structured by alternating transversal, growth ridges and furrows, oriented perpendicular to growth direction, corresponding to phases of rapid and low calcification. The specimens from the Stetten site lack such well-defined ridges. In all specimens of C. gryphoides analyzed by Harzhauser et al. (2010) for stable isotopes, the counting of increments would have resulted in a large overestimation of the life spans. Similarly, Alam and Das (1999) documented a clear misfit between growth increments and age for the extant $C$. madrasensis. Therefore, we restrict our age estimates solely to growth rates of $C$. gryphoides deduced from stable isotope profiles published by Harzhauser et al. (2010). According to these authors, a shell from Stetten attained $43 \mathrm{~cm}$ in length at an age of 11 years and the second one from a slightly younger horizon was $63 \mathrm{~cm}$ long at an age of 16 years. These values document an average growth rate of $\sim 3.9 \mathrm{~cm}$ per year and might serve as a base for rough age estimates for the complete adult shells from the Stetten shell bed.

For juvenile shells, this estimate would be wrong due to the non-linear mode of growth known from extant Crassostrea species, which show very high initial growth rates (Kennedy et al., 1996). Similarly, growth rates of Crassostrea gryphoides seem to decline in very old and large specimens as shown for a $78 \mathrm{~cm}$ long and 41-year-old shell from the upper Langhian of Austria (Harzhauser et al., 2010). To cope with the non-linear growth, growth curves of extant Crassostrea species are routinely calculated with the von Bertalanffy equation (von Bertalanffy, 1934). This equation is $\mathrm{SL}_{t}=\mathrm{SL}_{\text {max }}\left(1-e^{-k\left(t-t_{0}\right)}\right)$, where $\mathrm{SL}_{t}$ is shell length at time $t, \mathrm{SL}_{\max }$ is the asymptotic shell length, $t_{0}$ is the size at time 0 , and $k$ is a rate constant. Herein, we used the length of the center line of each shell as $\mathrm{SL}_{t}$ as this measure captures the real growth length of the partly strongly curved or sigmoid specimens. For $\mathrm{SL}_{\max }$ we used the size-to-age data of the $78 \mathrm{~cm}$ long shell, which is the largest individual known so far.

\subsection{Ratio between chalky and foliate layers}

The calcitic Crassostrea shells consist of two structures: thin but densely spaced foliate layers separated by thick layers of light-weight chalky material (Stenzel, 1971; Higuera-Ruiz and Elorza, 2009). This fast growing structure is interpreted to be a major adaptive advantage of Crassostrea to impede

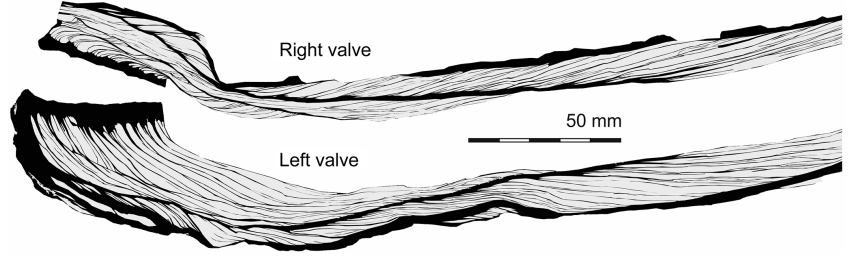

Figure 7. Longitudinal section through C. gryphoides from the oyster reef site showing the high amount of chalky layers (gray) and the low amount of foliate layers (black).

drilling predation and to prevent from sinking in the soft bottom (Seilacher, 1984; Chinzei, 1995; Kirby, 2001; Vermeij, 2014). In fossil shells the chalky layer is completely recrystallized and has the same density as the foliate layer. Nevertheless, it is optically easily recognized by its lighter color and the nearly opaque appearance. A polished longitudinal section of an articulated $C$. gryphoides shell (providing data for left and right shells) was scanned and the ratio between both shell structures was quantified by image analysis (Fig. 7). This method is only an approximation to the true value, as the ratio may vary locally (Durve and Bal, 1960; Chinzei, 1995), but it is clearly an improvement compared to former studies that used only linear transects or sectors within the shell (Durve and Bal, 1960; Chinzei, 1995; Kirby, 2001).

The image analysis of the cross-section documents proportions of 64 chalky to $36 \%$ foliate layers for the right shell and of 61 to $39 \%$ for the left shell. The density of the chalky layer when wet ranges around $1.15-1.32 \mathrm{~g} \mathrm{~cm}^{-3}$ (Chinzei, 1995) and the density of the foliate layer ranges around 2.2-2.5 $\mathrm{g} \mathrm{cm}^{-3}$ (Chinzei, 1995; Yoon et al., 2003) and has a clear upper limit by the density of calcite $\left(2.7 \mathrm{~g} \mathrm{~cm}^{-3}\right)$. Using 1.2 for the chalky layer and $2.2 \mathrm{~g} \mathrm{~cm}^{-3}$ for the foliate layer as rough estimates, mean density results in 1.84 and $1.81 \mathrm{~g} \mathrm{~cm}^{-3}$ for the right and left valves, respectively. Shell density in Crassostrea species is independent of age and size (Lombardi et al., 2013) and therefore the density estimates can be applied to the entire data set.

\subsection{Shell volume}

The volume of nine individual shells was determined using close-range laser scanning technology, which provides highresolution models with sub-mm resolution. The specimens were selected from the collections of the Natural History Museum and vary in center length from 141 to $406 \mathrm{~mm}$; four of these shells represent left-right shell pairs of an individual (Fig. 4). The data were captured with a measuring arm (METRIS MCA, 3600 M7). A hand-help triangulation laser scanner (a laser plane and a camera) was mounted at the end of two arms of fixed length with flexible joints. The laser scanner takes measurements with a maximum scan rate of 
80 stripes per second with a strip-width of about $200 \mathrm{~mm}$; the camera has a resolution of 1000 dots per strip.

In the first step, more than half of each shell was scanned and in the second step the other half. The overlap between both parts was more than $70 \%$, which was sufficient for successful registration of the scanned parts. During this registration process, the geometric transformation is determined, which puts the two 3-D laser point clouds together based on the points in the overlapping part. This procedure is done using the iterative closest point (ICP) algorithm (Glira et al., 2015). The resulting point cloud is analyzed in order to reduce noise and thus improve the surface description. Outliers (wrongly determined points not on the surface) were manually eliminated. Additionally, the raw point cloud (over 1.5 million points per shell) was uniformly sub-sampled to allow interactive handling. The final resolution is better than $0.18 \mathrm{~mm}$ (i.e., around 25 points per $\mathrm{mm}^{2}$ ). For volume calculation the point cloud has to be transformed into a closed mesh. Remaining holes, non-manifold surfaces and additional not connected components were identified and removed. Finally, the surface area of the mesh and its volume were computed using the algorithm of Mirtich (1996).

Based on the nine measured shells a relation between center line length and volume can be deduced. The largest shell measured is $406 \mathrm{~mm}$ long but no empirical volume data are available for larger shells, because these cannot be removed from the site. Therefore, the von Bertalanffy equation would not be applicable for shells larger than $\sim 40 \mathrm{~cm}$. Consequently, we chose a logistic function to approximate the inverse von Bertalanffy equation: $\vartheta=$ $\frac{3.2439 E 06}{1+118.86 e^{-0.009989} \mathrm{SL}}$, where $v$ is the volume in $\mathrm{mm}^{3}$ and $\mathrm{SL}$ the center line length in $\mathrm{mm}$ (Fig. 8). Applying this equation to all shells results in a total volume of $393273 \mathrm{~cm}^{3}$ with a mean shell volume of $350.8 \mathrm{~cm}^{3}(\sigma=313.7)$. These values do not change significantly if a non-linear Gompertz growth model is assumed as frequently done for Crassostrea (Lopes et al., 2013; Ginger et al., 2013). The respective equation $\vartheta=1.978 E 08 e^{-9.1404 e^{0.0013762 x}}$ results in a total volume of $398474 \mathrm{~cm}^{3}$. Applying the above-discussed average shell gravity of $1.82 \mathrm{~g} \mathrm{~cm}^{-3}$ results in a total carbonate mass of $\sim 715 \mathrm{~kg}$ (logistic) to $\sim 725 \mathrm{~kg}$ (Gompertz) for all 1121 shells. Thus, based on the age models of the shells, the annual carbonate production per shell can be calculated, which ranges from 74 ( $\sigma=2.9)$ (Gompertz) to $83 \mathrm{~g} \mathrm{yr}^{-1}(\sigma=2.8)$ (logistic), accounting for $\sim 150 \mathrm{~g} \mathrm{yr}^{-1}$ per living oyster individual (i.e., two valves).

\section{Discussion}

\subsection{From lengths to cohorts}

Based on the assumption that the size-frequency groups represent age classes it is apparent to establish length-at-age relationships. Applying the von Bertalanffy equation to the

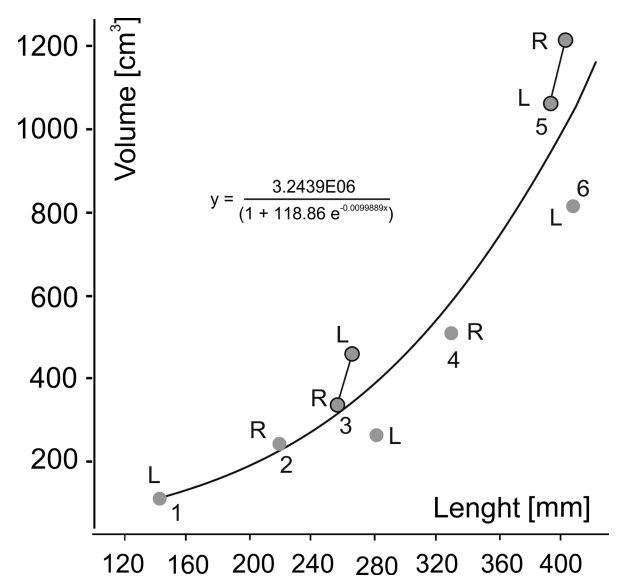

Figure 8. Logistic function showing the relation between center line length and shell volume based on empirical measurements of nine shells (dots); $\mathrm{L}=$ left shell, $\mathrm{R}=$ right shell; shell pairs are linked; numbers correspond to specimens illustrated in Fig. 4.

length data reveals a strongly right-skewed distribution with $50 \%$ of the shells ranging between 3 and 6 years (Fig. 9a). The frequency of specimens between 6 and 9 years decreases rapidly and the contribution by shells older than 9 years is subordinate although outliers with up to 16 years occur. Again the non-normal distribution of the von Bertalanffy growth model data suggests cohort mixing and the mixture analysis assumes at least four significant cohorts with low AIC value. Due to the rareness of large and aged shells, the fourth cohort displays a rather low amplitude and we assume that at least two natural cohorts may be amalgamated in this group. This suggests that more or less continuous recruitment accentuated by very successful settlement peaks every 2 or 3 years. Similarly, comparable patterns in extant Crassostrea reefs are linked to fluctuating mortality rates and changing recruitment success (Southworth et al., 2010). The data show that old and large shells are rare. The reason for this may be a generally high mortality during the early years of growth, resulting in low survival rates and few old specimens. The high amount of fragments of large shells, however, suggests that a distinctly higher proportion of large shells existed but became successively destroyed.

\subsection{Shell loss and mortality}

The rapid decline of old shells is a combination of two processes. First, natural mortality will result in a tail of large shells. Second, shells of died-off Crassostrea are known to have surprisingly short half-lives ranging from a few years to a few decades (Powell et al., 2006, 2015; Waldbusser et al., 2011). Natural degradation processes, such as fragmentation, dissolution and hydrodynamic export may account for $30 \%$ loss of shells per year (Southworth et al., 2010). The high amount of fragments with sharp edges suggests that fragmentation is a major factor in our case. The importance 


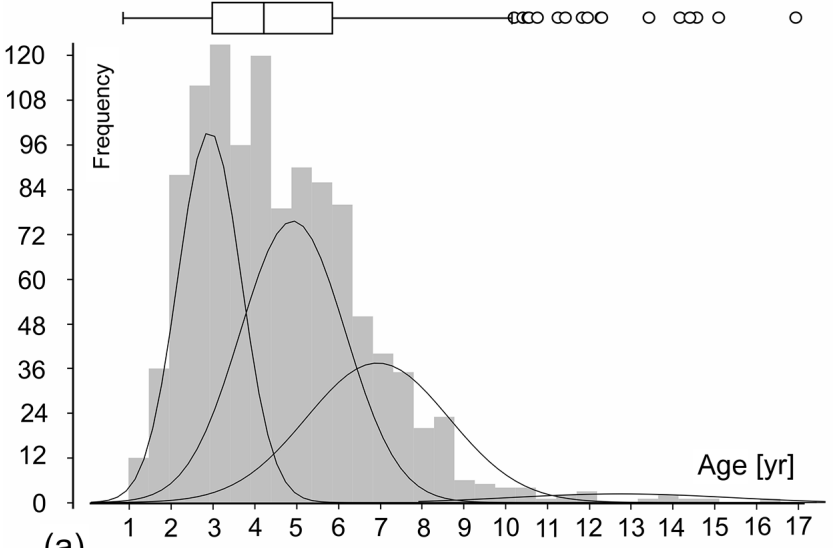

(a)

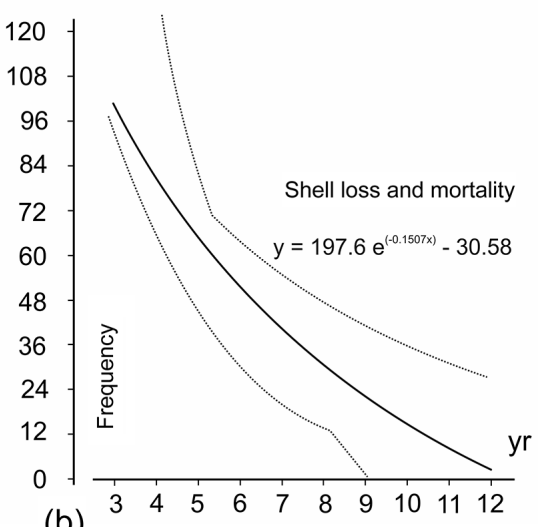

(b)

Figure 9. Age-frequency data and box-plot of the shells based on center length data transformed with the von Bertalanffy growth equation. Four cohorts are detected by mixture analysis (a). Combined effect of natural mortality and shell loss based on an exponential decay equation derived from the amplitudes of detected cohorts (dashed lines represent $95 \%$ confidence intervals) (b).

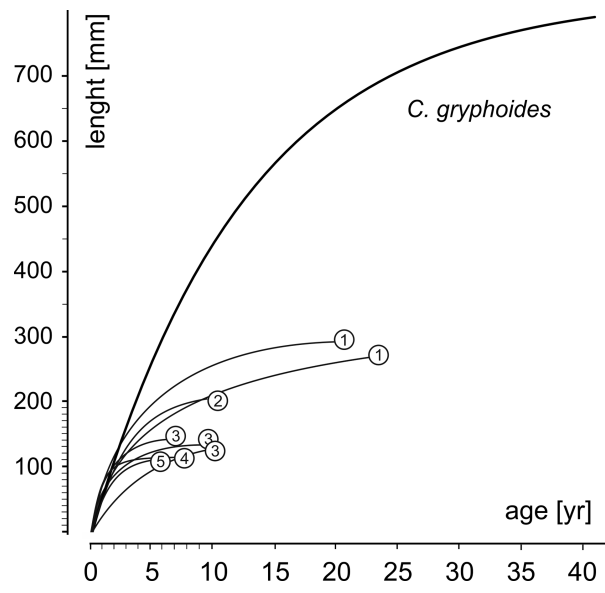

Figure 10. Comparison of von Bertalanffy growth model of Crassostrea gryphoides with selected fossil and extant Crassostrea species. 1: C. titan (Conrad, 1853), Miocene, California, USA (Kirby, 2001); 2: C. madrasensis (Preston, 1916), recent, Bangladesh (Nurul Amin et al., 2008); 3: C. virginica (Gmelin, 1791), recent and Pleistocene Virginia, USA (Kirby, 2001; Powell et al., 2011); 4: C. corteziensis (Hertlein, 1951), recent, Mexico (Chávez-Villalba et al., 2005); 5: C. gigas (Thunberg, 1793), recent, Marennes-Oleron, France (Berthome et al., 1986).

of hydrodynamic export cannot be evaluated due to the limited outcrop area. Dissolution, however, is a minor factor as the well-preserved shell-surfaces lack any signs of chemical degradation. Based on the declining amplitudes of the cohorts the total shell loss can be computed as an exponential decay function (Fig. 9b) revealing initial half-lives of less than 4 years. The high proportion of fragmented, abraded and/or bioeroded oyster shells (fragments: $n=7047$ ) would balance the "missing frequencies" easily. We have no evi- dence for age-specific shell destruction and assume that all age classes were equally affected by fragmentation.

Overall, under the environmental conditions as present in the Early Miocene estuary, a died-off Crassostrea gryphoides reef would have been fully degraded within 1 or 2 decades if not buried below the taphonomically active zone (Olszewski, 2004). The high sedimentation rates in the rapidly subsiding basin with rates $\left(0.6 \mathrm{~m} \mathrm{kyr}^{-1}\right.$, Zuschin et al., 2014), warranted a rapid burial of the reef, thus capturing the population structure.

\subsection{Crassostrea as carbonate factory?}

The image-analysis-based estimation of chalky and foliate layers shows that the values for chalky layers are slightly lower than reported for other fast-growing Crassostrea species. The volume of chalky layers in left shells of the extant Crassostrea "gryphoides" (sensu Newton and Smith, 1912) is $\sim 70 \%$ (Durve and Bal, 1960). The shells of the Miocene Crassostrea titan (Conrad, 1853) and C. gravitesta (Yokoyama, 1926) were reported to comprise even up to $\sim 90 \%$ of chalky deposits (Chinzei, 1995; Kirby, 2001) but this may be a slight overestimation, neglecting the high amount of dense calcite in the hinge areas. A reevaluation of the illustrated specimen of $C$. gravitesta in Chinzei (1995) using our method reveals a somewhat lower but still high value of $77 \%$ chalky layer. The gravity of the fast-growing $C$. titan, C. gravitesta and C. cahobasensis (Pilsbry and Brown, 1917) was estimated to range around $1.35-1.40 \mathrm{~g} \mathrm{~cm}^{-3}$ (Chinzei, 1995; Kirby and Jackson, 2004). These values are very close to the empirical data on the fast growing C. ariakensis (Fujita, 1913) $\left(1.44 \pm 0.12 \mathrm{~g} \mathrm{~cm}^{-3}\right)$ measured by Lombardi et al. (2013). Slightly higher values are given for $C$. gigas $\left(1.63 \pm 0.35 \mathrm{~g} \mathrm{~cm}^{-3}\right.$, mean $\left.=1.58\right)$ by Chinzei (1995). Generally, species with low amounts of chalky layer have much higher densities; e.g., C. vir 
ginica shells range around $2.18-2.35 \mathrm{~g} \mathrm{~cm}^{-3}$ (Kirby and Jackson, 2004; Lombardi et al., 2013). Our gravity estimate of $\sim 1.82 \mathrm{~g} \mathrm{~cm}^{-3}$ for $C$. gryphoides is thus somewhat higher than expected for such a growth type. In fact, large parts of the shells are very light-weighed and fit well to the patterns discussed by Chinzei (1995) and Kirby (2001). The main difference is the large proportion of heavy shell material in the huge umbos and hinges.

A comparison of the growth curve of $C$. gryphoides with the von Bertalanffy growth models of fossil and extant Crassostrea species (Fig. 10) reveals this oyster to be an outstandingly fast growing species. Thus, $C$. gryphoides was an important carbonate producer in Neogene estuaries and lagoons where it lived as a secondary soft-bottom dweller in dense colonies in a mixed mode of shell-supported reclining and mud sticking (sensu Seilacher et al., 1985; Seilacher and Gishlick, 2014). Therefore, dense populations with more than 100 individuals per $\mathrm{m}^{2}$ can be expected. Even within the shell bed, which is clearly not in situ, the average density is 129 shells $\left(\sim 64\right.$ individuals) per $\mathrm{m}^{2}$ (including also moderately fragmented shells). This would point to a hypothetic annual carbonate production of up to $15 \mathrm{~kg} \mathrm{~m}^{-2}$ with the oyster reef. Although this calculation is just a very rough estimate, it indicates that the carbonate production is in the range of fast growing coral reefs with productions of $6-10 \mathrm{~kg} \mathrm{~m}^{-2} \mathrm{yr}^{-1}$ (Montaggioni, 2005; Jones et al., 2015). A major difference, however, is the rapid shell loss in Crassostrea reefs, which prevents the formation of rigid and stable structures comparable to coral reefs.

\section{Conclusions}

Crassostrea gryphoides was the fastest growing and largest Crassostreinae species known so far. Despite the fact that this species could attain outstanding individual ages of four decades (Harzhauser et al., 2010), the bulk of specimens analyzed herein lived less than 10 years, typically growing up to about $300 \mathrm{~mm}$ in length.

The non-normal distribution in the size, area and agefrequency data are best explained by the presence of distinct recruitment cohorts, comparable to modern oyster reefs. About four cohorts are detected by mixture analysis and the rapidly decreasing amplitudes of frequency of these cohorts is interpreted to reflect the combined effect of mortality, the declining life expectancy with age, and the shell loss by biotic and physical factors. As no accumulation of large and aged shells occurred, whilst the amount of fragments is high, we assume that shell loss is an important factor to explain the strongly right-skewed distribution. Shell halflives ranged around 2-4 years and within less than 2 decades the seemingly rigid and persisting structure of a Crassostrea gryphoides reef could have been completely degraded. This may explain the rareness of in situ C. gryphoides reefs in the fossil record although the shells are frequent and ubiquitous.
The significant growth rate is clearly boosted by the formation of up to $64 \%$ percentage of fast-growing and lightweight chalky material. The subtropical climate with warm winter temperatures above ca. $10^{\circ} \mathrm{C}$ and the nutrient-rich setting in an estuary will additionally have supported the excessive growth.

Due to its fast growth and large shells, the carbonate production of $C$. gryphoides is outstanding. Dense colonies might have produced around $15 \mathrm{~kg} \mathrm{~m}^{-2} \mathrm{yr}^{-1}$ of carbonate, which is within the range of fast growing coral reefs. Therefore, this oyster may have been a major carbonate producer in the circum-Tethyan area throughout the Miocene. In contrast to coral reefs, however, the high shell loss rates did not allow stable persistent structures to form.

\section{Information about the Supplement}

Supplement Table: Center line length and area data for 1121 complete shells of Crassostrea gryphoides. Age, volume and carbonate mass data are derived from the equations discussed in the text.

\section{The Supplement related to this article is available online at doi:10.5194/bg-13-1223-2016-supplement.}

Acknowledgements. The study was financed by the Austrian Science Fund (FWF project no. P 25883-N29 "Smart-Geology für das größte fossile Austernriff der Welt"). We would like to thank Florian Rist from the Institute of Art and Design, Vienna University of Technology for providing access to the photo studio and for his support during data acquisition. We thank Hisao Ando and two anonymous reviewers for their detailed reviews and constructive comments. We thank Eetu Puttonen for his help with the implementation of automated center line algorithm.

Edited by: H. Kitazato

\section{References}

Afsar, N., Siddiqui, G., and Roberts, D.: Parasite inspection in five commercially important oyster species (Mollusca: Bivalvia) of Pakistan, J. Basic Appl. Sci., 10, 220-225, 2014.

Aichholzer, O., Aurenhammer, F., Alberts, D., and Gärtner, B.: A novel type of skeleton for polygons. Springer, Berlin, Heidelberg, 752-761, 1996.

Alam, M. D. and Das, N. G.: Growth and age determination of an intertidal cupped oyster Crassostrea madrasensis (Preston) (Bivalvia: Ostreidae) around Moheshkhali Channel, Bay of Bengal, Indian J. Mar. Sci., 28, 329-331, 1999.

Baqueiro Cárdenas, E. R. and Aldana Aranda, D.: Differences in the exploited oyster (Crassostrea virginica (Gmelin, 1791)) populations from different coastal lagoons of the Gulf of Mexico, Transitional Waters Bull., 2, 21-35, 2007. 
Berthome, J. P., Prou, J., and Bodoy, A.: Performances de croissance de l'huître creuse, Crassostrea gigas (Thunberg) dans le bassin d'élevage de Marennes-Oléron entre 1979 and 1982, Haliotis, 15, 183-192, 1986.

Chatterji, A., Ansari, Z. A., Ingole, B. S., and Parulekar, A. H.: Length-weight relationship of giant oyster Crassostrea gryphoides (Schlotheim), Mahasagar-Bull. Nat. Inst. Oceanogr., 18, 521-524, 1985.

Chávez-Villalba, J., López-Tapia, M., Mazón-Suástegui, J., and Robles-Mungaray, M.: Growth of the oyster Crassostrea corteziensis (Hertlein, 1951) in Sonora, Mexico. Aquac. Res., 36, 1337-1344, 2005.

Chinzei, K.: Morphological and structural adaptations to soft substrates in the Early Jurassic monomyarians Lithiotis and Cochlearites, Lethaia, 15, 179-197, 1982.

Chinzei, K.: Shell structure, growth, and functional morphology of an elongate Cretaceous oyster, Palaeontology, 29, 139-154, 1986.

Chinzei, K.: Adaptive significance of the lightweight shell structure in soft bottom oysters, Neues Jahrb. Geol. P.-A., 195, 217-227, 1995.

Chinzei, K.: Adaptation of oysters to life on soft substrates, Hist. Biol., 25, 223-231, 2013.

Chinzei, K. and Seilacher. A.: Remote biomineralization I: fill skeletons in vesicular oyster shells, N. Jb. Geol. Paläont. Abh., 190, 349-361, 1993.

Coakley, J. M.: Growth of the eastern oyster, Crassostrea virginica, in: Chesapeake Bay, Thesis, Faculty of the Graduate School of the University of Maryland, 1-263, 2004.

Conrad, T. A.: Notes on shells with descriptions of new species, P. Acad. Nat. Sci. Phila., 6, 199-200, 1853.

Delaunay, B.: Sur la sphere vide, Otdelenie Matematicheskikh i Estestvennykh Nauk, 7, 793-800, 1934.

Dellmour, R. and Harzhauser, M.: The Iván Canyon, a large Miocene canyon in the Alpine-Carpathian Foredeep, Mar. Petrol. Geol., 38, 83-94, 2012.

Dempster, A. P., Laird, N. M., and Rubin, D. B.: Maximum likelihood from incomplete data via the EM algorithm, J. Roy. Stat. Soc. B, 39, 1-38, 1977.

Durve, V. S.: Malacological differences between the oysters Crassostrea gryphoides (Schlotheim) and Crassostrea madrasensis Preston, Indian J. Fish., 202, 624-625, 1974.

Durve, V. S. and Bal, D. V.: Some observations on shell-deposits of the oyster Crassostrea gryphoides (Schlotheim), P. Indian AS-B, 54, 45-55, 1960.

Einsele, G., Ricken, W., and Seilacher, A.: Cycles and events in stratigraphy, Springer-Verlag, Berlin, 1-955, 1991.

FAO: Food and Agriculture Organization of the United Nations, Fisheries and Aquaculture Department, Aquaculture Fact Sheets, http://www.fao.org/fishery/culturedspecies/search/ en (last access: 14 May 2015), 2015.

Fujita, T.: Nihon Suisan Dobutsugaku (Aquatic Zoology in Japan, Shokabo, Tokyo, Japanese aquatic fisheries animals), vol 2., Shokabu, Tokyo, 1-292, 1913.

Ginger, K. W. K., Vera, C. B. S., Dineshram, R., Dennis, C. K. S., Adela, L. J., Yu, Z., and Thiyagarajan, V.: Larval and post-larval stages of Pacific oyster (Crassostrea gigas) are resistant to elevated $\mathrm{CO}_{2}$, PLoS ONE, 8, e64147, doi:10.1371/journal.pone.0064147, 2013.
Glira, P., Pfeifer, N., Briese, C., and Ressl, C.: A correspondence framework for ALS strip adjustments based on variants of the ICP Algorithm, PFG Photogrammetrie, Fernerkundung, Geoinformation, 4, 275-289, 2015.

Gmelin, J. F.: Caroli a Linnei systema natura per regna tria naturae, secundum classes, ordines, genera, species, cum characteribus, disserentis, synonymis, locis etc. Editio decima tertia, aucta, reformata, cura J. F. Gmelin, 1, Vermes testacea, G. E. Beer, Lipsiae, 3021-4120, 1791.

Goldner, A., Herold, N., and Huber, M.: The challenge of simulating the warmth of the mid-Miocene climatic optimum in CESM1, Clim. Past, 10, 523-536, doi:10.5194/cp-10-523-2014, 2014.

Groslier, T., Toft Christensen, H., Davids, J., Dolmer, P., Elmedal, I., Holm, M. W., and Hansen, B. W.: Status of the Pacific Oyster Crassostrea gigas (Thunberg, 1793) in the western Limfjord, Denmark - Five years of population development, Aquat. Invas., 9, 175-182, 2014.

Hammer, Ø.: PAST, Paleontological Statistics Version 3.06, Reference manual. Natural History Museum, University of Oslo, p. 225, 2015.

Hammer, Ø., Harper, D. A. T., and Ryan, P. D.: Past: Paleontological Statistics Software Package for Education and Data Analysis, Palaeontol. Electron., 4, 1-9, 2001.

Harding, J. M., Mann, R., and Southworth, M. J.: Shell length-atage relationships in James River, Virginia oysters (Crassostrea virginica) collected four centuries apart, J. Shellfish Res., 27, 1109-1115, 2008.

Harzhauser, M., Böhme, M., Mandic, O., and Hofmann, Ch.-Ch.: The Karpatian (Late Burdigalian) of the Korneuburg Basin - a palaeoecological and biostratigraphical synthesis, Beitr. Paläont., 27, 441-456, 2002.

Harzhauser, M., Piller, W. E., Müllegger, S., Grunert, P., and Micheels, A.: Changing seasonality patterns in Central Europe from Miocene Climate Optimum to Miocene Climate Transition deduced from the Crassostrea isotope archive, Glob. Planet. Change, 76, 77-84, 2010.

Harzhauser, M., Djuricic, A., Mandic, O, Zuschin, M., Dorninger, P., Nothegger, C., Székely, B., Puttonen, E., Molnár, G., and Pfeifer, N.: Disentangling the history of complex multi-phased shell beds based on the analysis of 3D point cloud data, Palaeogeogr. Palaeoecol., 437, 165-180, 2015.

Hertlein, L. G.: Descriptions of two new species of marine pelecypods from west Mexico, Southern Calif. Acad. Sci. Bull., 50, 68-75, 1951.

Higuera-Ruiz, R. and Elorza, J.: Biometric, microstructural, and high-resolution trace element studies in Crassostrea gigas of Cantabria (Bay of Biscay, Spain): anthropogenic and seasonal influences, Estuar. Coast. Shelf S., 82, 201-213, 2009.

Hoşgör, I.: Presence of Crassostrea gryphoides (Schlotheim) from the lower-middle Miocene sequence of Kahramanmarap Basin (SE Turkey); its taxonomy, paleoecology and paleogeography, Min. Res. Explor. Bull., 136, 17-28, 2008.

Jones, N. S., Ridgwell, A., and Hendy, E. J.: Evaluation of coral reef carbonate production models at a global scale, Biogeosciences, 12, 1339-1356, doi:10.5194/bg-12-1339-2015, 2015.

Kazhdan, M., Bolitho, M., and Hoppe, H.: Poisson surface reconstruction, Proceedings of the fourth Eurographics symposium on Geometry processing, 7, 61-70, 2006. 
Kennedy, V. S., Newell, R. I. E., and Eble, A. F.: The Eastern Oyster Crassostrea virginica, College Park, Maryland, USA, Maryland Sea Grant College Publication UM-SG-TS-96-01, 1-750, 1996.

Kern, A., Harzhauser, M., Mandic, O., Roetzel, R., Ćorić, S., Bruch, A. A., and Zuschin, M.: Millennial-scale vegetation dynamics in an estuary at the onset of the Miocene Climate Optimum, Palaeogeogr. Palaeoecol., 304, 247-261, 2010.

Kidwell, S. M.: Models for fossil concentrations: Paleobiologic implications, Paleobiology, 12, 6-24, 1986.

Kidwell, S. M.: The stratigraphy of shell concentrations, in: Taphonomy, Releasing the Data Locked in the Fossil Record, edited by: Allison, P. A. and Briggs, D. E. G., Plenum Press, New York, 211-290, 1991.

Kirby, M. X.: Paleoecological differences between Tertiary and Quaternary Crassostrea oysters, as revealed by stable isotope sclerochronology, Palaios, 15, 132-141, 2000.

Kirby, M. X.: Differences in growth rate and environment between Tertiary and Quaternary Crassostrea oysters, Paleobiology, 27, 84-103, 2001.

Kirby, M. X. and Jackson, J. B. C.: Extinction of a fastgrowing oyster and changing ocean circulation in Pliocene Tropical America, Geology, 32, 1025-1028, 2004.

Kirby, M. X., Soniat, T. M., and Spero, H. J.: Stable isotope sclerochronology of Pleistocene and Recent oyster shells (Crassostrea virginica), Palaios, 13, 560-569, 1998.

Kirk, J.: Advanced Dijkstra's minimum path algorithm, http://www.mathworks.com/matlabcentral/fileexchange/ 20025-advanced-dijkstras-minimum-path-algorithm, last access: 2 April 2015, 2015.

Koeppen, W.: Das geographische System der Klimate, in: Handbuch der Klimatologie, edited by: Koeppen, W. and Geiger, R., Gebrüder Bornträger, Berlin, 1-44, 1936.

Kraus, K. and Pfeifer, N.: Advanced DTM generation from LIDAR data, Int. Arch. Photogr. Remote Sensing Spatial Inf. Sci., 34, 23-30, 2001.

Laurain, M.: Crassostrea gryphoides et $C$. gingensis (Schlotheim, 1813) deux expressions morphologiques d'une même espèce (Miocène, Bivalvia), Geobios, 13, 21-43, 1980.

Littlewood, D. T. J.: Molecular phylogenetics of cupped oysters based on partial 28S rDNA gene sequences, Mol. Phylogenet. Evol., 3, 221-229, 1994.

Lombardi, S. A., Chon, G. D., Jin-Wu Lee, J., Lane, H. A., and Paynter, K. T.: Shell hardness and compressive strength of the Eastern oyster, Crassostrea virginica, and the Asian oyster, Crassostrea ariakensis, Biol. Bull., 225, 175-183, 2013.

Lopes, G. R., Araujo de Miranda Gomes, C. H., Tureck, C. R., and de Melo, C. M. R.: Growth of Crassostrea gasar cultured in marine and estuary environments in Brazilian waters, Pesqui. Agropecu. Bras., 48, 975-982, 2013.

Mahar, M. A. and Awan, K. P.: Cultivation of oyster Crassostrea gryphoides (Schlotheim) through rafts at Ambra creek coastal belt of Arabian sea, Sindh Pakistan, Sindh Univ. Res. J., 44, 119124, 2012.

Mancera, E. and Mendo, J.: Population dynamics of the oyster Crassostrea rhizophorae from the Cienaga Grande de Santa Marta, Colombia. Fish. Res., 26, 139-148, 1996.

Mandic, O., Harzhauser, M., Schlaf, J., Piller, W. E., Schuster, F., Wielandt-Schuster, U., Nebelsick, J. H., Kroh, A., Rögl, F., and Bassant, P.: Palaeoenvironmental Reconstruction of an epiconti- nental Flooding - Burdigalian (Early Miocene) of the Mut Basin (Southern Turkey), Cour. Forsch.-Inst. Senckenberg, 248, 57-92, 2004.

Marshall, B.: Magallana Salvi, Macali \& Mariottini, 2014. Accessed through: World Register of Marine Species, available at: http://marinespecies.org/aphia.php?p=taxdetails\&id=836032, last access: 8 April 2015, 2015.

Mirtich, B.: Fast and accurate computation of polyhedral mass properties, J. Graphics Tools, 1, 31-50, 1996.

Montaggioni, L. F.: History of Indo-Pacific coral reef systems since the last glaciation: development patterns and controlling factors, Earth-Sci. Rev., 71, 1-75, 2005.

Nagi, H. M., Shenai-Tirodkar, P. S., and Jagtap, T. G.: Dimensional relationship in Crassostrea madrasensis (Preston) and $C$. gryphoides (Schlotheim) in mangrove ecosystem, Indian J. GeoMar. Sci., 40, 559-566, 2011.

Newton, R. B. and Smith. E. A.: On the survival of a Miocene oyster in Recent seas, Rec. Geol. Surv. India, 42, 1-15, 1912.

Nothegger, C. and Dorninger, P.: 3D filtering of high-resolution Terrestrial Laser Scanner point clouds for cultural heritage documentation, Photogram., Fernerkundung, Geoinf., 1, 53-63, 2009.

Nurul Amin, S. M., Zafar, M., and Halim, A.: Age, growth, mortality and population structure of the oyster, Crassostrea madrasensis, in the Moheskhali Channel (southeastern coast of Bangladesh), J. Appl. Ichthyol., 24, 18-25, 2008.

Ó Foighil, D., Gaffney, P. M., and Hilbish, T. J.: Differences in mitochondrial $16 \mathrm{~S}$ ribosomal gene sequences allow discrimination among [Crassostrea virginica (Gmelin)] and Asian [C. gigas (Thunberg), C. ariakensis Wakiya] oyster species, J. Exp. Mar. Biol. Ecol., 192, 211-220, 1995.

Olszewski, T.: Modeling the influence of taphonomic destruction, reworking, and burial on time-averaging in fossil accumulations, Palaios, 19, 39-50, 2004.

Otepka, J., Ghuffar, S., Waldhauser, C., Hochreiter, R., and Pfeifer, N.: Georeferenced point clouds: A survey of features and point cloud management, ISPRS Int. J. Geo-Inf., 2, 1038-1065, 2013

Peel, M. C., Finlayson, B. L., and McMahon, T. A.: Updated world map of the Köppen-Geiger climate classification, Hydrol. Earth Syst. Sci., 11, 1633-1644, doi:10.5194/hess-11-16332007, 2007.

Pfeifer, N., Mandlburger, G., Otepka, J., and Karel, W.: OPALS A framework for airborne laser scanning data analysis, Comput. Environ. Urban, 45, 125-136, 2014.

Pilsbry, H. A. and Brown, A.: Oligocene fossils from the neighborhood of Cartagena, Colombia, with notes on some Haitian species, P. Acad. Nat. Sci. Phila., 69, 32-41, 1917.

Powell, E. N., Kraeuter, J. N., and Ashton-Alcox, K. A.: How long does oyster shell last on an oyster reef?, Estuar. Coast. Shelf S., 69, 531-542, 2006.

Powell, E. N., Klinck, J. M., Guo, X., Ford, S. E., and Bushek, D.: The potential for oysters, Crassostrea virginica, to develop resistance to Dermo disease in the field: evaluation using a genebased population dynamics model, J. Shellfish Res., 30, 685712, 2011.

Powell, E. N., Mann, R., Ashton-Alcox, K. A., Kim, Y., and Bushek, D.: The allometry of oysters: spatial and temporal variation in the length-biomass relationships for Crassostrea virginica, J. Mar. Biol. Assoc. UK, online first, 18 pp., 2015. 
Preston, H. B.: Report on a collection of Mollusca from the Cochin and Ennur Backwaters, Rec. Indian Mus., 12, 27-39, 1916.

Ragaini, L. and Di Celma, C.: Shell structure, taphonomy and mode of life of a Pleistocene ostreid from Ecuador, Boll. Soc. Paleont. Ital., 48, 79-87, 2009.

Reece, K. S., Cordes, J. F., Stubbs, J. B., Hudson, K. L., and Francis, E. A.: Molecular phylogenies help resolve taxonomic confusion with Asian Crassostrea oyster species, Mar. Biol., 153, 709-721, 2008.

Ren, J., Liu, X., Jiang, F., Guo, X., and Liu, B.: Unusual conservation of mitochondrial gene order in Crassostrea oysters: evidence for recent speciation in Asia, BMC Evol. Biol., 10, 394, doi:10.1186/1471-2148-10-394, 2010.

Robinson, E. M., Lunt, J., Marshall, C. D., and Smee, D. J.: Eastern oysters Crassostrea virginica deter crab predators by altering their morphology in response to crab cues, Aquat. Biol., 20, 11118, 2014.

Ross, P. G. and Luckenbach, M. W.: Population Assessment of Eastern Oysters (Crassostrea virginica) in the Seaside Coastal Bays. Final Report. Virginia Coastal Zone Management Program, College of William and Mary, Wachapreague, 101 pp., 2009.

Sacco, F.: I molluschi dei terreni terziarii del Piemonte e della Liguria, Parte XXIII, Pelecypoda (Ostreidae, Anomiidae e Dimyidae), Carlo Clausen, Torino, 1-46, 1897.

Salvi, D., Macali, A., and Mariottini, P.: Molecular phylogenetics and systematics of the bivalve family Ostreidae based on rRNA sequence-structure models and multilocus species tree, PLoS ONE, 9, e108696, doi:10.1371/journal.pone.0108696, 2014.

Schultz, O.: Bivalvia neogenica (Nuculacea - Unionacea), in: Catalogus Fossilium Austriae, Wien, edited by: Piller, W. E., Akademie der Wissenschaften, 1/1, 1-379, 2001.

Seilacher, A.: Constructional morphology of bivalves: evolutionary pathways in primary versus secondary soft-bottom dwellers, Palaeontology, 27, 207-237, 1984.

Seilacher, A. and Gishlick, A. D.: Morphodynamics, CRS Press, 1551,2014

Seilacher, A., Matyja, B. A., and Wierzbowski, A.: Oyster Beds: Morphologic response to changing substrate conditions, Lect. Notes Earth Sci., 1, 421-435, 1985.

Siddiqui, G. and Ahmed, M.: Oyster species of the sub tropical coast of Pakistan (northern Arabian Sea), Indian J. Mar. Sci., 31, 108$118,2002$.

Southworth, M., Harding, J. M., Wesson, J. A., and Mann, R.: Oyster (Crassostrea virginica, Gmelin 1791) population dynamics on public reefs in the Great Wicomico River, Virginia, USA, J. Shellfish Res., 29, 271-290, 2010.

Sovis, W. and Schmid, B.: Das Karpat des Korneuburger Beckens, Teil 1. Beitr. Paläont., 23, 1-413, 1998. Sovis, W. and Schmid, B.: Das Karpat des Korneuburger Beckens, Teil 2. Beitr. Paläont., 27, 1-467, 2002.

Sowerby, G. B.: Monograph of the genus Ostraea, Conchologia Iconica, 18, 6-33, 1871.

Stenzel, H. B.: Oysters, in: Treatise on Invertebrate Paleontology, edited by: Moore, R. C., Geological Society of America and the University of Kansas Press, Lawrence, N/3, 953-1224, 1971.

Thunberg, C. P.: Tekning och Beskrifning på en stor Ostronsort ifrån Japan, Kongliga Vetenskaps Academiens Nya Handlingar, 14, 140-142, 1793.
Trivedi, S., Aloufi, A. A., Ansari, A. A., and Ghosh, S. K.: Molecular phylogeny of oysters belonging to the genus Crassostrea through DNA barcoding, J. Entomol. Zool. Stud., 3, 21-26, 2015.

Vermeij, G.: The oyster enigma variations: a hypothesis of microbial calcification, Paleobiology, 40, 1-13, 2014.

von Bertalanffy, L.: Untersuchungen über die Gesetzmäßigkeiten des Wachstums, I. Allgemeine Grundlagen der Theorie; mathematische und physiologische Gesetzlichkeiten des Wachstums bei Wassertieren, Arch. Entwicklungsmech. Org., 131, 613-652, 1934.

von Schlotheim, E. F.: Beiträge zur Naturgeschichte der Versteinerungen in geognostischer Hinsicht, in: Leonhard's Taschenbuch für die gesammte Mineralogie mit Hinsicht auf die neuesten Entdeckungen, edited by: Leonhard, C. C., Series 1, 7, 1-134, 1813.

Voronoi, G.: Nouvelles applications des paramètres continus à la théorie des formes quadratiques. Deuxième mémoire, Recherches sur les parallélloèdres primitifs, J. Reine Angew. Math., 133, 97-178, 1908.

Waldbusser, G. G., Steenson, R. A., and Gren, M. A.: Oyster shell dissolution rates in estuarine waters: effects of $\mathrm{pH}$ and shell legacy, J. Shellfish Res., 30, 659-669, 2011.

Wang, Y., Xus, Z., and Guo, X.: Differences in the rDNA-bearing chromosome divide the Asian-Pacific and Atlantic species of Crassostrea (Bivalvia, Mollusca), Biol. Bull., 206, 46-54, 2004.

Wessely, G.: Geologie des Korneuburger Beckens, Beitr. Paläont., 23, 9-23, 1998.

Wiedl, T., Harzhauser, M., Kroh, A., Ćorić, S., and Piller, W. E.: Ecospace variability along a carbonate platform at the northern boundary of the Miocene reef belt (Upper Langhian, Austria), Palaeogeogr. Palaeocol., 370, 232-246, 2013.

Yokoyama, M.: Fossil Mollusca from the oil-fields of Akita, J. Fac. Sci., Imperial Univ. Tokyo, Sect. 2, 1/9, 377-389, 1926.

Yoon, G.-L., Kim, B.-T., Kim, B.-O., and Han, S.-H.: Chemicalmechanical characteristics of crushed oyster-shell, Waste Manag., 23, 825-834, 2003.

Zachos, J. C., Dickens, G. R., and Zeebe, R. E.: An early Cenozoic perspective on greenhouse warming and carbon-cycle dynamics, Nature, 451, 279-283, 2008.

Zhang, G., Fang, X., Guo, X., Li, L., Luo, R., Xu, F., Yang, P., Zhang, L., Wang, X., Qi, H., Xiong, Z., Que, H., Xie, Y., Holland, P. W., Paps, J., Zhu, Y., Wu, F., Chen, Y., Wang, J., Peng, C., Meng, J., Yang, L., Liu, J., Wen, B., Zhang, N., Huang, Z., Zhu, Q., Feng, Y., Mount, A., Hedgecock, D., Xu, Z., Liu, Y., Domazet-Lošo, T., Du, Y., Sun, X., Zhang, S., Liu, B., Cheng, P., Jiang, X., Li, J., Fan, D., Wang, W., Fu, W., Wang, T., Wang, B., Zhang, J., Peng, Z., Li, Y., Li, N., Wang, J., Chen, M., He, Y., Tan, F., Song, X., Zheng, Q., Huang, R., Yang, H., Du, X., Chen, L., Yang, M., Gaffney, P. M., Wang, S., Luo, L., She, Z., Ming, Y., Huang, W., Zhang, S., Huang, B., Zhang, Y., Qu, T., Ni, P., Miao, G., Wang, J., Wang, Q., Steinberg, C. E., Wang, H., Li, N., Qian, L., Zhang, G., Li, Y., Yang, H., Liu, X., Wang, J., Yin, Y., and Wang, J.: The oyster genome reveals stress adaptation and complexity of shell formation, Nature, 490, 49-54, 2012.

Zuschin, M., Harzhauser, M., Hengst, B., Mandic, O., and Roetzel, R.: Long-term ecosystem stability in an Early Miocene estuary, Geology, 42, 1-4, 2014. 